\title{
Functional Requirement on Proofreading System
}

\author{
Dita Lupita Sari*, Choirun Niswatin \\ Politeknik Kota Malang, Tlogowaru No.3, Malang, East Java, Indonesia 65133. \\ * Corresponding author. Tel.: +62 0341754 088; email: ditalupitasari@gmail.com \\ Manuscript submitted February 4, 2019; accepted April 28, 2019. \\ doi: 10.17706/jsw.14.5.192-199
}

\begin{abstract}
This research aims to have an analysis on functional requirements to build the proofreading system. It is used to justify the appropriateness of functional requirements which gained from interview to the project owners and end users' questionnaires. Kano method is applied to compare both of data from interview and questionnaires. It classifies the provides features into some categories to measure the users' satisfaction level. The result of Kano evaluation shows that only one out of 17 features is not important in the perspective of users. In contrast, other features are important for them, however, each of features should be determined into its priority to develop the system using Kano. The system development must be started from features which are prioritized the criteria be $(M)$ followed by one-dimensional $(0)$ then attractive (A). There are 6 features which are differently perceived between lectures' and students' point of view. This differentiation makes project owners difficult to prioritize the features development since the weaknesses of Kano which could not disclose the users' reasons..
\end{abstract}

Key words: Abstract, functional requirement, kano, proofreading system.

\section{Introduction}

English is an international language for global communication. Therefore, the government of Indonesia pays attention more to increase its nationals' English proficiency [1]. One of the government policies makes English becomes a mandatory subject at schools including university level [2]. This makes students enhance a-four-English skill; listening; reading, speaking, and writing [1].

Huge of researches show that academic writing is the most difficult skill faced by ESL students [4] particularly for those whose background is not English discipline such as engineering students [4]. However, the universities generally require them to write their final project in English language particularly abstract which is part of it, written into Indonesian and English. In consequence, they tend to commit to error when writing their abstract in English as the preliminary studies on 100 documents of abstract written by engineering students at Politeknik Kota Malang showing that around 47\% did not fulfill the requirement format of abstract. Furthermore, there were 582 errors in linguistics. One of the reasons that might cause the errors was only few of them (14.1\%) did proofread their work due to the limited number of lectures as well as time [5]. To overcome it, this paper aims to design an application system of proofreading on academic writing such as abstract, since it is the important part of research report which mostly makes the readers skim it first before scanning all passages. The use of English in writing abstract emerges to publish the research findings to worldwide letting open the partnership in the future research [5].

To begin with the application system, needs analysis to users had been carried out to investigate the features that they really need which is called functional requirement. It identifies the specific and vital role 
on what product must do and which one that must be delivered at particular time [6]..

This research delivers functional requirement to have general trend of the needs comparison between project owners and those of end users. The comparison is aimed to obtain the best features of the system. To have this comparison, Kano method is applied to this research. The Kano is frequently utilized to measure the customers' satisfaction. It determines the type of features which give more than the mean level of customers' satisfaction. On the other hand, it also finalizes the other features which make satisfaction if the system provides them, but makes dissatisfaction when they are not provided [7].

There are two problem statements to explore the best result in doing functional requirement:

1) Is there any appropriateness of the project owner' functional requirement and those belong to end user?

2) What are features obtained from the functional requirement?

\section{Method}

\subsection{Data Collection}

To collect the data, the interview had been conducted to the project owners; English lectures at Politeknik Kota Malang. The interview aims to obtain the project owner' needs as the main data to build the system. Subsequently, these data are transferred to type of features in functional system.

Those data serve as the foundation to formulate questionnaire distributing to the end users; students and lecturers . These students are preparing the report of final project at Politeknik Kota Malang as well as the 2-year- alumni from the same polytechnics. The questionnaires are set under the frame of Kano method to seek the end users' satisfaction towards the features recommended by the project owners. The same questionnaire is given to the lecturer as well then, its result compares to the end users to figure out the appropriateness.

\subsection{Kano Method}

Kano method which was introduced by Noriaki Kano from Tokyo Riko University discloses the quality of the product features in the perspective of customers. The method lets the system have conception in depth on customers' satisfaction [8]. This model differs the three types of required product which influences customers' satisfaction [9]:

1) Must be (basic) needs

2) This is the essential needs and must be obtained because this is extremely important for customers. The needs could be available on the product or service. If the product or the service could not fulfill the needs, the customers completely felt dissatisfaction.

3) One-dimensional (performance) needs

This is the proportional needs. It means that, if the needs are fulfilled, then the customers' satisfaction will increase. In contrast, if the needs are not fulfilled, the customers' satisfaction remains decrease.

4) Attractive (Excitement) needs

5) This is the added value needs if they are fulfilled. However, if the needs do not come in to exist, they do not make the customers dissatisfaction

6) However, there are three other categorizations instead of the aforementioned above:

7) Indifferent

8) Customers ignore to the availability of the certain attribute; thus, they do not care whether it is available or not.

9) Questionable 
10) This category occurs when there are contradictive responses from the users. This indicates that there is misconstruction on questions, misconception on the question, or wrong responses.

11) Reverse

12) This means that some of customers' satisfaction decreases to this question, however, they actually want the opposite condition instead

The questionnaire which uses Kano method covers questions in the type of functional and difunctional [10]. Each of question response covers the options such as: like, must-be, neutral, live with, and dislike. These responses are converted to Kano table as seen in Table 1, thus, the appropriateness of the needs between functional system and users could be clearly identified [11].

Table 1. Kano Evaluation

\begin{tabular}{|c|c|c|c|c|c|c|}
\hline \multirow{2}{*}{\multicolumn{2}{|c|}{$\begin{array}{l}\text { Customer } \\
\text { Requirements } \rightarrow\end{array}$}} & \multicolumn{5}{|c|}{ Dysfunctional } \\
\hline & & \multirow{2}{*}{$\begin{array}{l}1 . \\
\text { like } \\
\mathrm{Q}\end{array}$} & \multirow{2}{*}{$\begin{array}{c}\begin{array}{c}2 . \\
\text { must-be }\end{array} \\
\text { A } \\
\end{array}$} & \multirow{2}{*}{$\begin{array}{c}\begin{array}{c}3 . \\
\text { neutral }\end{array} \\
\mathrm{A} \\
\end{array}$} & \multirow{2}{*}{$\begin{array}{c}\begin{array}{c}4 . \\
\text { live with }\end{array} \\
\mathrm{A} \\
\end{array}$} & \multirow{2}{*}{$\begin{array}{c}5 . \\
\text { dislike } \\
\mathrm{O} \\
\end{array}$} \\
\hline \multirow{5}{*}{$\begin{array}{l}\text { Func- } \\
\text { tional }\end{array}$} & 1. like & & & & & \\
\hline & 2. must-be & $\mathrm{R}$ & I & I & I & $\mathrm{M}$ \\
\hline & 3. neutral & $\mathrm{R}$ & I & I & I & $\mathrm{M}$ \\
\hline & 4. live with & $\mathrm{R}$ & I & I & I & $\mathrm{M}$ \\
\hline & 5. dislike & $\mathrm{R}$ & $\mathrm{R}$ & $\mathrm{R}$ & $\mathrm{R}$ & $\mathrm{Q}$ \\
\hline
\end{tabular}

It is apparently seen from Table 1 that the needs covered in the question is determined into A (Attractive), $M$ (Must-Be), $O$ (One-Dimensional), $R$ (Reverse), $Q$ (Questionable), and $I$ (Indifferent).

After evaluating the needs using Kano table, they are determined to Kano categorization applying Blauth Formula; calculating each of categorization. The biggest total number is the one which becomes the definite category. Therefore, if the customers' requirement allows $(M+O+A)>(R+I+Q)$, the maximum category from $(M+O+A)$ will be the definite one. If it is $(M+O+A)<(R+I+Q)$, the maximum category from $(R+I+Q)$ will be determined as definite category [9].

When finished with Kano categorization, it comes to the Better and Worse calculation. The former indicates how high the customers' satisfaction if the features are available (A\&0). Contractively, Worse indicates how low the customers' satisfaction if the features are not available (O\&M). The following formula is used to find the worse and better:

$$
\begin{gathered}
\text { Better }=\frac{A+O}{A+O+M+I} \\
\text { Worse }=\frac{O+M}{A+O+M+I}
\end{gathered}
$$

\section{Finding and Discussion}

\subsection{Data Collection}

List of functional requirements has been yielded from the interview of two English lecturers at Politeknik Kota Malang. The list consists of 17 features needed building the proofreading system:

1) Correction request

2) Limitation of correction request 
3) Acceptability/rejection information request

4) Abstract template

5) View of corrected abstract by lectures

6) Revision abstract format

7) View of linguistic correction

8) Revision linguistic errors

9) Chat with lectures

10) Information status of abstract (under review/finish) for each step of correction

11) Limitation of correction number

12) Abstract printing

13) View of individuals corrected abstract

14) View of all individuals list of abstract

15) View of all linguistic errors list

16) View of abstract list of classified discipline

17) Search on abstract titles and keywords

The 17 functional requirements had been constructed to questions item in the type of functional and dysfunctional features in questionnaires. The questionnaires had been distributed to students and lectures. There are 44 respondents who filled them listing 34 students and 10 lectures.

\subsection{Kano Evaluation}

Collected data from the questionnaires which had been categorized into 2 types of end users had been analyzed using Kano method. The former data is obtained from students as seen in Table 2. Meanwhile, the latter is from the lectures as presented in Table 3. Both of data are formulated into Kano table (see Table 1) determining Kano categorization.

Table 2. Kano Categorization of Students as End Users

\begin{tabular}{|r|r|r|r|r|r|r|r|r|r|l|}
\hline CR & A & M & R & O & Q & I & O+A+M & I+R+Q & Tot & Grade \\
\hline 1 & 6 & 9 & 0 & 10 & 1 & 8 & 25 & 9 & 34 & 0 \\
\hline 2 & 9 & 2 & 8 & 6 & 0 & 9 & 17 & 17 & 34 & A \\
\hline 3 & 0 & 11 & 2 & 15 & 1 & 5 & 26 & 8 & 34 & 0 \\
\hline 4 & 6 & 8 & 1 & 12 & 1 & 6 & 26 & 8 & 34 & 0 \\
\hline 5 & 5 & 10 & 0 & 12 & 0 & 7 & 27 & 7 & 34 & 0 \\
\hline 6 & 3 & 6 & 0 & 16 & 1 & 8 & 25 & 9 & 34 & 0 \\
\hline 7 & 3 & 9 & 1 & 13 & 1 & 7 & 25 & 9 & 34 & 0 \\
\hline 8 & 6 & 6 & 1 & 12 & 2 & 7 & 24 & 10 & 34 & 0 \\
\hline 9 & 10 & 5 & 0 & 10 & 1 & 8 & 25 & 9 & 34 & A \\
\hline 10 & 5 & 12 & 0 & 10 & 1 & 6 & 27 & 7 & 34 & M \\
\hline 11 & 3 & 5 & 7 & 3 & 1 & 15 & 11 & 23 & 34 & I \\
\hline 12 & 6 & 8 & 0 & 13 & 0 & 7 & 27 & 7 & 34 & 0 \\
\hline 13 & 6 & 8 & 1 & 12 & 1 & 6 & 26 & 8 & 34 & 0 \\
\hline 14 & 6 & 10 & 1 & 8 & 0 & 9 & 24 & 10 & 34 & 0 \\
\hline 15 & 3 & 8 & 2 & 11 & 0 & 10 & 22 & 12 & 34 & M \\
\hline 16 & 4 & 4 & 1 & 11 & 0 & 14 & 19 & 15 & 34 & 0 \\
\hline 17 & 3 & 10 & 0 & 15 & 1 & 5 & 28 & 6 & 34 & 0 \\
\hline
\end{tabular}


Table 3. Kano Categorization of Lectures as End Users

\begin{tabular}{|r|r|r|r|r|r|r|r|r|r|l|}
\hline $\mathrm{CR}$ & $\mathrm{A}$ & $\mathrm{M}$ & $\mathrm{R}$ & $\mathrm{O}$ & $\mathrm{Q}$ & $\mathrm{I}$ & $\mathrm{O}+\mathrm{A}+\mathrm{M}$ & $\mathrm{I}+\mathrm{R}+\mathrm{Q}$ & Total & Grade \\
\hline 1 & 3 & 2 & 0 & 3 & 0 & 2 & 8 & 2 & 10 & 0 \\
\hline 2 & 0 & 3 & 1 & 3 & 1 & 2 & 6 & 4 & 10 & 0 \\
\hline 3 & 1 & 4 & 0 & 5 & 0 & 0 & 10 & 0 & 10 & 0 \\
\hline 4 & 0 & 5 & 0 & 5 & 0 & 0 & 10 & 0 & 10 & 0 \\
\hline 5 & 1 & 4 & 0 & 4 & 0 & 1 & 9 & 1 & 10 & 0 \\
\hline 6 & 1 & 5 & 0 & 3 & 0 & 1 & 9 & 1 & 10 & $\mathrm{M}$ \\
\hline 7 & 0 & 3 & 0 & 6 & 0 & 1 & 9 & 1 & 10 & 0 \\
\hline 8 & 0 & 4 & 0 & 5 & 0 & 1 & 9 & 1 & 10 & 0 \\
\hline 9 & 3 & 3 & 1 & 0 & 0 & 3 & 6 & 4 & 10 & $\mathrm{~A}$ \\
\hline 10 & 1 & 6 & 0 & 3 & 0 & 0 & 10 & 0 & 10 & $\mathrm{M}$ \\
\hline 11 & 1 & 1 & 2 & 0 & 0 & 6 & 2 & 8 & 10 & $\mathrm{I}$ \\
\hline 12 & 0 & 5 & 0 & 3 & 0 & 2 & 8 & 2 & 10 & $\mathrm{M}$ \\
\hline 13 & 0 & 5 & 0 & 2 & 0 & 3 & 7 & 3 & 10 & $\mathrm{M}$ \\
\hline 14 & 1 & 2 & 1 & 1 & 0 & 5 & 4 & 6 & 10 & $\mathrm{I}$ \\
\hline 15 & 2 & 2 & 0 & 5 & 0 & 1 & 9 & 1 & 10 & 0 \\
\hline 16 & 2 & 2 & 0 & 5 & 0 & 1 & 9 & 1 & 10 & 0 \\
\hline 17 & 1 & 3 & 0 & 5 & 0 & 1 & 9 & 1 & 10 & 0 \\
\hline
\end{tabular}

Collected data from the questionnaires which had been categorized into 2 types of end users had been analyzed using Kano method. The former data is obtained from students as seen in Table 2. Meanwhile, the latter is from the lectures as presented in Table 3. Both of data are formulated into Kano table (see Table 1) determining Kano categorization.

Tabel 4. Kano Evaluation of Students and Lecturer as End Users

\begin{tabular}{|r|l|c|c|c|c|c|c|}
\hline CR & \multicolumn{1}{|c|}{$\begin{array}{c}\text { Functional } \\
\text { Requirement }\end{array}$} & $\begin{array}{c}\text { Better } \\
\text { (Student) }\end{array}$ & $\begin{array}{c}\text { Better } \\
\text { (Lecturer) }\end{array}$ & Average & $\begin{array}{c}\text { Worse } \\
\text { (Student) }\end{array}$ & $\begin{array}{c}\text { Worse } \\
\text { (Lecturer) }\end{array}$ & Average \\
\hline 1 & Correction request & 0,48 & 0,60 & 0,54 & 0,58 & 0,50 & 0,54 \\
\hline 2 & $\begin{array}{l}\text { Limitation of } \\
\text { correction request }\end{array}$ & 0,58 & 0,38 & 0,48 & 0,31 & 0,75 & 0,53 \\
\hline 3 & $\begin{array}{l}\text { Acceptability/rejection } \\
\text { information request }\end{array}$ & 0,48 & 0,60 & 0,54 & 0,84 & 0,90 & 0,87 \\
\hline 4 & Abstract template & 0,56 & 0,50 & 0,53 & 0,63 & 1,00 & 0,82 \\
\hline 5 & $\begin{array}{l}\text { View of corrected } \\
\text { abstract by lectures }\end{array}$ & 0,50 & 0,50 & 0,50 & 0,65 & 0,80 & 0,73 \\
\hline 6 & $\begin{array}{l}\text { Revision abstract } \\
\text { format }\end{array}$ & 0,58 & 0,40 & 0,49 & 0,67 & 0,80 & 0,74 \\
\hline 7 & $\begin{array}{l}\text { View of linguistic } \\
\text { correction }\end{array}$ & 0,50 & 0,60 & 0,55 & 0,69 & 0,90 & 0,80 \\
\hline 8 & $\begin{array}{l}\text { Revision linguistic } \\
\text { errors }\end{array}$ & 0,58 & 0,50 & 0,54 & 0,58 & 0,90 & 0,74 \\
\hline 9 & Chat with lectures & 0,61 & 0,33 & 0,47 & 0,45 & 0,33 & 0,39 \\
\hline & $\begin{array}{l}\text { Information status of } \\
\text { abstract (under } \\
\text { review/finish) for each } \\
\text { step of correction }\end{array}$ & 0,45 & 0,40 & 0,43 & 0,67 & 0,90 & 0,79 \\
\hline 11 & $\begin{array}{l}\text { Limitation of } \\
\text { correction number }\end{array}$ & 0,23 & 0,13 & 0,18 & 0,31 & 0,13 & 0,22 \\
\hline 12 & Abstract printing & 0,56 & 0,30 & 0,43 & 0,62 & 0,80 & 0,71 \\
\hline 13 & $\begin{array}{l}\text { View of individuals } \\
\text { corrected abstract }\end{array}$ & 0,56 & 0,20 & 0,38 & 0,63 & 0,70 & 0,67 \\
\hline 14 & View of all individuals & 0,42 & 0,22 & 0,32 & 0,55 & 0,33 & 0,44 \\
\hline
\end{tabular}




\begin{tabular}{|c|l|c|c|c|c|c|c|}
\hline & list of abstract & & & & & & \\
\hline 15 & $\begin{array}{l}\text { View of all linguistic } \\
\text { errors list }\end{array}$ & 0,44 & 0,70 & 0,57 & 0,59 & 0,70 & 0,65 \\
\hline 16 & $\begin{array}{l}\text { View of abstract list of } \\
\text { classified discipline }\end{array}$ & 0,45 & 0,70 & 0,58 & 0,45 & 0,70 & 0,58 \\
\hline 17 & $\begin{array}{l}\text { Search on abstract } \\
\text { titles and keywords }\end{array}$ & 0,55 & 0,60 & 0,58 & 0,76 & 0,80 & 0,78 \\
\hline
\end{tabular}

Table 5 . Kano Categorization Result

\begin{tabular}{|c|c|c|c|c|}
\hline $\mathrm{CR}$ & $\begin{array}{c}\text { Functional } \\
\text { Requirement }\end{array}$ & $\begin{array}{c}\text { Grade } \\
\text { (Student) }\end{array}$ & $\begin{array}{c}\text { Grade } \\
\text { (Lecturer) }\end{array}$ & Result \\
\hline 1 & Correction request & 0 & 0 & 0 \\
\hline 2 & $\begin{array}{l}\text { Limitation of } \\
\text { correction request }\end{array}$ & $\mathrm{A}$ & 0 & 0 \\
\hline 3 & $\begin{array}{l}\text { Acceptability/rejection } \\
\text { information request }\end{array}$ & 0 & 0 & 0 \\
\hline 4 & Abstract template & 0 & 0 & 0 \\
\hline 5 & $\begin{array}{l}\text { View of corrected } \\
\text { abstract by lectures }\end{array}$ & 0 & 0 & 0 \\
\hline 6 & $\begin{array}{l}\text { Revision abstract } \\
\text { format }\end{array}$ & 0 & $\mathrm{M}$ & $\mathrm{M}$ \\
\hline 7 & $\begin{array}{l}\text { View of linguistic } \\
\text { correction }\end{array}$ & 0 & 0 & 0 \\
\hline 8 & $\begin{array}{l}\text { Revision linguistic } \\
\text { errors }\end{array}$ & 0 & 0 & 0 \\
\hline 9 & Chat with lectures & $\mathrm{A}$ & A & A \\
\hline 10 & $\begin{array}{l}\text { Information status of } \\
\text { abstract (under } \\
\text { review/finish) for each } \\
\text { step of correction }\end{array}$ & $\mathrm{M}$ & $\mathrm{M}$ & M \\
\hline 11 & $\begin{array}{l}\text { Limitation of } \\
\text { correction number }\end{array}$ & $\mathrm{I}$ & I & I \\
\hline 12 & Abstract printing & 0 & $\mathrm{M}$ & 0 \\
\hline 13 & $\begin{array}{l}\text { View of individuals } \\
\text { corrected abstract }\end{array}$ & 0 & $\mathrm{M}$ & $\mathrm{M}$ \\
\hline 14 & $\begin{array}{l}\text { View of all individuals } \\
\text { list of abstract }\end{array}$ & 0 & I & 0 \\
\hline 15 & $\begin{array}{l}\text { View of all linguistic } \\
\text { errors list }\end{array}$ & $\mathrm{M}$ & 0 & 0 \\
\hline 16 & $\begin{array}{l}\text { View of abstract list of } \\
\text { classified discipline }\end{array}$ & 0 & 0 & 0 \\
\hline 17 & $\begin{array}{l}\text { Search on abstract } \\
\text { titles and keywords }\end{array}$ & 0 & 0 & 0 \\
\hline
\end{tabular}

\subsection{Discussion}

The system offers 17 functional requirement features, however, only 6 features are differently viewed by end users; students and lectures as seen in Table 5. The 6 features are no. 2, 6, 12, 13, 14, and 15; under the features' name: limitation of correction, revision of abstract format; abstract printing; view of individuals abstract list; view of all abstract list; view of linguistic errors respectively. As a matter of fact, only one feature; no.14 is significantly different. In the perspective of students, the feature is categorized as one-dimensional $(0)$ meaning that the availability of such feature increases the users' satisfaction and vise verse. Meanwhile, the lectures perceive it indifferent (I) showing that the users do not care about the availability. As clearly seen in Kano evaluation (Table 4), there is no significantly different between students and lectures towards the feature with the ratio 0.32:0.44 (better and worse respectively). This means that the satisfaction does not matter. Other three of features are not significantly different for they are the ultimate requirement. Nevertheless, the project owner had better decide on clear categorization of three 
features in priority scale. Due to the unclear categorization of the features could give negative impact on the project owners [8]. Therefore, a personal discussion has been carried out with the project owners to determine the final result of Kano categorization for each feature as seen in Table 5. However, it is undeniable that such condition is not that easy for Kano's weaknesses. It could not gain the reason form the users concerning about the ambiguous categorization of the features [9].

The only feature; no.11 (limitation of number of correction) is the lowest users' satisfaction level and categorizes it as indifferent (I). It means that the users do not pay attention much on the availability of such feature. The findings suggest to the project owners to delete it. The clearer categorized features the easier software developer to determine the priority scale to develop the system [12]. As a result, the development of proofreading system had better start from the features which are categorized them into must-be (M) followed by one-dimensional $(0)$ then attractive $(A)$. This priority influences to the users' satisfaction so it should be taken into account.

In conclusion, most of provided features meet the users' demand which are categorized as must be one-dimensional and attractive). Unfortunately, one feature is suggested to be disappeared for it is not important for the users as it is categorized as indifferent. In other words, the majority of the offered features are acceptable for developing the proofreading system.

\section{References}

[1] Waloyo, E. (2017). The implementation of mind mapping technique in teaching writing: A case study at Man 13 Jakarta. ELT Echo : The Journal of English Language Teaching in Foreign Language Context.

[2] Indonesia, R. (2005). Peraturan pemerintah RI Nomor 19 Tahun 2005 Tentang Standar Nasional Pendidikan. Depdiknas.

[3] Fadda, H. A. (2012). Difficulties in academic writing: From the perspective of king saud university postgraduate students. English Language Teaching.

[4] Xiao, G. \& Chen, X. (2015). English academic writing difficulties of engineering students at the tertiary level in China. World Transactions on Engineering and Technology Education, 13, 259-263.

[5] Niswatin, C., Latief, M. A., \& Suharyadi, S. (2018). How do the polytechnic students cope with the difficulties in composing abstracts for their final projects? IOP Conference Series: Materials Science and Engineering, 306.

[6] Gilb, T. (1997). Principles of Software Engineering Management. Reading: Addison Wesley Longman.

[7] Tontini, G. (2000). Identification of customer attractive and must-be requirements using a modified Kano's method: Guidelines and case study. Annual Quality Congress Proceedings-American Society for Quality Control.

[8] Berger, C. et al. (1993). Kano's methods for understanding customer-defined quality. The Center for Quality Management Journal.

[9] Wijaya, T. (2011). Manajemen kualitas jasa: Desain servqual, Qfd, dan Kano disertai contoh aplikasi dalam kasus penelitian. Jakarta: PT. Indeks.

[10] Mustakim, A., Anggraeni, S., \& Sirajuddin. (2017). Analisis kualitas layanan dengan metode kano berdasarkan dimensi servqual pada PT. Jurnal Teknik Industri Untirta.

[11] Sari, D. L., \& Niswatin, C. (2018). System requirement analysis for e-learning materials to support academic writing skills for engineering students of vocational higher education. Jurnal Pendidikan Vokasi.

[12] Nurhayati, S. (2014). Analisis kebutuhan proses bisnis menggunakan metode kano. Jurusan Teknik Komputer Fakultas Teknik dan Ilmu Komputer Universitas Komputer Indonesia. 


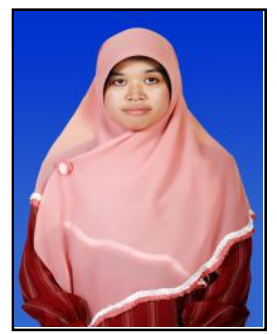

Dita Lupita Sari was born in Malang-Indonesia on 06 January 1987. She was undergradute of informatics at the Department of Informatics Engineering, Electronic Engineering Polytechnic Institute of Surabaya in 2009. After defended her master dissertation entitled Analysis and Design Architecture of Beatme Integrated System she got her master degree in the smae field of study at School of Electrical Engineering and Informatics, Bandung Institute of Technology in 2014, Indonesia.

Currently, she works as a lecturer at informatic Department of Politeknik Kota Malang-Indonesia. Her research is software engineering. She published an article entitiled System requirement analysis for e-learning materials to support academic writing skills for engineering students of vocational higher education.

Ms Sari was awardee as the first winner in creative idea in developing software held by Indosat Wireless Innovation Contest. 